ks. Radostaw Kimsza

Politechnika Biatostocka

\title{
Życie konsekrowane a ekumenizm
}

\section{THE CONSECRATED LIFE AND ECUMENISM}

The consecrated life is the following of Jesus Christ through a life of chastity, poverty and obedience. It was born in the Christian east of the undivided Church. From there it was transferred to the Christian west and took various forms. They were rejected by the Reformation. This state survived until the twentieth century. That can be called a kind of renaissance of consecrated life in the Protestant churches. The resulting monastic communities also open to other Christian denominations. The consecrated life filled with constant prayer leading to personal conversion and spousal union with Christ, which are considered the foundation of the ecumenical movement and its purpose.

Key words: monasticism, ecumenism, chastity, poverty, obedience, reformation, Taizé, Bose.

Rok 2015, ogłoszony przez Papieża Franciszka Rokiem Życia Konsekrowanego jest okazją do odnowienia katolickiego spojrzenia na życie ewangelicznymi radami czystości, ubóstwa i posłuszeństwa, a także odnalezienia go w innych Kościołach i wspólnotach chrześcijańskich oraz wskazanie jego ekumenicznej perspektywy.

Choć życie zakonne narodziło się na chrześcijańskim Wschodzie, to odnajdujemy je także, już we wczesnym chrześcijaństwie, także na gruncie Kościoła łacińskiego, a także Kościołów, które wyrosły z reformacji. I choć zarówno Marcin Luter, jak i Huldrych Zwingli pogardzali tymi, którzy nie żenili się i za mąż nie wychodzili, to jednak w tzw. Kościołach i wspólnotach ewangelikalnych odnajdujemy 
mężczyzn i kobiety, którzy podejmują próbę życia wspólnotowego na dialogu wzór Chrystusa bezżennego, czystego, ubogiego i posłusznego.

\section{Źródła życia konsekrowanego?}

Realizacja powołania chrześcijańskiego polega na naśladowaniu Jezusa Chrystusa. Do IV wieku uważano, że można to czynić jedynie przez „męczeństwo krwi”. To przekonanie potwierdza sposób śmierci pierwszych uczniów Chrystusa. Według przekazu Tradycji spośród dwunastu Apostołów jedenastu poniosło śmierć męczeńską. Po nich swoją przynależność do Jezusa przypieczętowała męczeńską krwią niezliczona rzesza męczenników aren Cesarstwa Rzymskiego. Imiona wielu z nich są zapisane w Martyrologium Romanum.

Kres męczeństwu pierwszych wieków chrześcijaństwa położył podpisany w Mediolanie w 313 roku przez cesarza Konstantyna i Licyniusza edykt, który wprowadził tzw. tolerancję religijną. Odtąd chrześcijanie i inni obywatele Cesarstwa Wschodniego i Zachodniego mogli swobodnie wyznawać swoją religię ${ }^{1}$.

Znikły, przynajmniej na jakiś czas, areny męczeństwa za wiarę w Jezusa Chrystusa, a ci, którzy pragnęli Go naśladować zaczęli zastanawiać się jak można to zrobić w niekrwawy sposób.

Odkryto wówczas, że oprócz „męczeństwa krwi” istnieje „męczeństwo duchowe" polegające na oddaniu się na własność Bogu w życiu monastycznym. Było to tzw. cotidianum martyrium - codzienne męczeństwo ${ }^{2}$.

Żyjący na przełomie IV i V wieku propagator monastycyzmu wschodniego na Zachodzie, święty Kościoła prawosławnego, Jan Kasjan istotę tego rodzaju męczeństwa upatrywał w wyrzeczeniu się własnej woli i surowości podejmowanego przez mnichów życia. W jednej z rozmów, zapisanych w przetłumaczonym na język polski dziele Rozmów dwadzieścia cztery miał powiedzieć: „,[mnisi] w raz obranym powołaniu trwają z takim poświęceniem, że nigdy nie pełnią swojej własnej woli, i tak cierpliwość i surowość życia ukrzyżowała ich dla tego świata, czyniąc z nich codziennie żywych męczenników"3.

„Żywi męczennicy” naśladowali Jezusa poprzez życie w czystości, ubóstwie i posłuszeństwie.

Por. W. Doroszkiewicz, Dzieje wschodnich Rzymian, Białystok 2012, s. 17.

Por. E. Malone, The Monk and the Martyr, [w:] B. Steidle, Antonius Magnus Eremita, Roma 1956, s. 201. 


\section{Bezżenna czystość}

Autor Listu do Hebrajczyków stwierdza: „Takiego właśnie nam trzeba było arcykapłana świętego, niewinnego, nieskalanego, odłączonego od grzeszników, sięgającego ponad niebo" (Hbr 7, 26-27). Użyte w tym przypadku greckie słowo a fizyczną czystość powiązaną nierozerwalnie ze sprawowanym kultem. Stąd żydowskie ablucje, które poprzez symboliczne obmycia czyniły człowieka gotowym do modlitwy, składania ofiary czy też uwalniały od zaciągniętej tzw. rytualnej nieczystości.

Wspomniany termin odnosił się także do czystości dziewiczej, oznaczającej rezygnację z jakichkolwiek form zaspokojenia popędu seksualnego. Jeśli według autora Listu do Hebrajczyków Chrystus jest

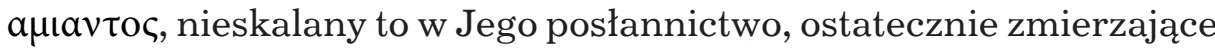
do złożenia zadośćczynnej ofiary za grzechy człowieka, wpisane jest także dziewictwo ${ }^{4}$. Jest ono źródłem ewangelicznej „bezżenności dla królestwa niebieskiego" (por. Mt 19,12).

Niewątpliwym źródłem czystości Jezusa jest także Jego udział w wewnętrznym życiu Trójcy Świętej, definiowanym przez teologię jako doskonała Miłość. Dialog dwunastoletniego Jezusa z Maryją i Józefem w Świątyni Jerozolimskiej: „Nie wiecie, że powinienem być w tym, co należy do mego Ojca" (Łk 2,49) odnosił się nie tylko do miejsca, ale także do ontycznej jedności z Ojcem i Duchem Świętym. Nie może więc ona dopuszczać niczego, co powiązane byłoby z brakiem doskonałości, tym bardziej duchowo-fizycznej integralności.

W bezżennej czystości żył także „największy narodzony z niewiast” (Mt 11,11) - św. Jan Chrzciciel. Ikonografia bizantyjska przedstawia go jako „Anioła pustyni”, prostującego drogi na przyjście Pana (por. Łk $1,76 ; \mathrm{Mk} 1,3)$ i w ten sposób wypełniającego starotestamentalną zapowiedź Izajasza: „Drogę dla Pana przygotujcie na pustyni, wyrównajcie na pustkowiu gościniec naszemu Bogu!” (Iz 40,3).

Jana Chrzciciela łączą z Chrystusem nie tylko więzy krwi, ale także zanurzona w ontycznej czystości oblubieńcza przyjaźń. Jan jest „Przyjacielem Oblubieńca, który stoi i słucha go, raduje się niezmiernie słysząc głos oblubieńca" (J 3,29) dzięki czemu może złożyć świadectwo, że Jezus z Nazaretu jest Synem Bożym (por. J 1,34).

Z racji na życie w oblubieńczej czystości Kościół Wschodni, poświadczają to teksty liturgiczne, nazywa Jana Chrzciciela „aniołem w ciele”, „aniołem na ziemi”. Stan jego życia umieszcza go w bliskości Chrystusa

Por. A. Amato, Il celibato di Gesù, Watykan 2010, s. 3. 
Pantokratora na ikonach Deesis, na równi z Theotokos - przenikniętą ontyczną czystością ${ }^{5}$.

Taka motywacja towarzyszyła pierwszym mnichom i mniszkom w podejmowaniu życia w bezżennej czystości. Odnajdywała ona swoje źródło w Jezusie Chrystusie i w Jemu najbliższych: kuzynie i przyjacielu - św. Janie Chrzcicielu oraz Theotokos - Maryi.

Jednakże nie tylko poprzez bezżenną czystość miał eremita, czy mnich upodabniać się do Chrystusa, żyć w tzw. bezkrwawym męczeństwie. W Chrystusie odnajdywał on także ideał ubóstwa i ubogim chciał także się stawać.

\section{Ubóstwo}

Życie w ewangelicznym ubóstwie znajdowało swoją motywację nie gdzie indziej, jak tylko w Osobie Jezusa Chrystusa, Tym, który „ogołocił samego siebie" (Flp 2,7), „będąc bogatym stał się ubogim” (2 Kor 8,9).

Ubogim było życie Jezusa w Nazarecie. Ewangelista Marek łączy Go z zawodem cieśli (por. Mk 6,3). Także u św. Mateusza Jezus, przez sobie współczesnych, jest rozpoznawany jako syn cieśli (por. Mt 13,55). Zawód ten był szanowany i pozwalał na przeciętne życie. Wiele jednak wskazuje na to, że ukryte życie Jezusa Chrystusa powiązane było z pracą na roli. Świadczy o tym Jego doskonała znajomość uprawy ziemi wyrażona w licznych przypowieściach ( $46 \mathrm{z}$ nich odnosi się pośrednio bądź bezpośrednio do roli). Badacze dziejów Jezusa skłaniają się ku przekonaniu, że w czasie tzw. życia ukrytego porzucił On zawód cieśli, aby jeszcze bardziej przybliżyć się do ubogich, podzielić ich styl życia. Praca na roli, potwierdza to ewangeliczna przypowieść o robotnikach w winnicy (por. Mt 20,1-16), nie była opłacalna. Najmujący się otrzymywali dniówkę ok. 1 denara, za które, według Apokalipsy św. Jana można było nabyć kwartę pszenicy i trzy kwarty jęczmienia (por. Ap 6,6). Także samego siebie Jezus przyrównywał do pracującego na roli: siewcy siejącego dobre nasienie (por. Mt 13,7) czy dobrego pasterza (por. J 10,11) .

Ubogi styl życia monastycznego był nierozerwalnie złączony z ziemią. Eremici, mnisi uprawiali ziemię, czerpiąc z niej to, co konieczne do życia, ale także dzięki pracy na roli byli bliżej ubogich i mogli z nimi

5 Por. J. Popowicz, Największy spośród niewiast zrodzony, „Przegląd Prawosławny" 9(2006), s. 10.

Por. R. Brandstaetter, Czy Jezus z Nazarethu byt cieślą?, [w:] idem, Jezus z Nazarethu, t. 1-4, Kraków 2013, s. 14 nn. 
dzielić się jej owocami a także uczyć nowatorskich metod agrarnych polepszając dotychczasowy sposób życia rolnika. Przyczynił się do tego m.in. założony w XI wieku, oparty na regule benedyktyńskiej Zakon Cystersów.

Podejmując życie w ewangelicznym ubóstwie mnisi chcieli naśladować Chrystusa ogołoconego na krzyżu. Wówczas to Odkupiciel człowieka to wszystko, co należało do ziemi pozostawił i taki został zabrany do nieba.

\section{Posłuszeństwo}

W Ewangelii wedtug św. Jana (por. J 6,38) oraz w paralelnym tekście w Ewangelii wedtug św. Mateusza (por. Mt 26,39) czytamy, że Jezus przyszedł na świat, by wypełnić wolę Tego, który Go posłał.

Poprzez życie w ewangelicznym posłuszeństwie mnich dążył do tzw. stanu edenicznego, jaki towarzyszył człowiekowi przed grzechem pierworodnym, człowieka posłusznego Bogu w zachowywaniu Jego zakazów (por. Rdz 2,16-17). Chcąc osiągnąć taki stan mnich starał się żyć w posłuszeństwie Słowu Bożemu, zakonnej regule oraz przełożonemu, który miał być wyrazicielem woli Boga w doczesności.

O ewangeliczne posłuszeństwo, uwarunkowane pokorą wsparło się życie monastyczne chrześcijańskiego Wschodu i Zachodu. Jego reformy powracały zawsze do pierwotnego, i jeszcze bardziej pogłębionego rozumienia posłuszeństwa, przekraczającego granice tzw. ślepego posłuszeństwa i wprowadzającego w odnajdywanie tego, co rzeczywiście służy zbawczej perspektywie i przeciwstawia prymat własnej woli na korzyść woli Tego, który najbardziej wie, co potrzebne jest człowiekowi (por. Mt 6,3). Sobór Watykański II przypomnial, że osoby konsekrowane powinny być posłuszne „w duchu wiary, poruszone przez Ducha Świętego i w duchu umiłowania woli Bożej”7.

\section{Życie monastyczne na chrześcijańskim Wschodzie}

Życie radami ewangelicznymi, jak już zostało wspomniane, narodziło się na chrześcijańskim Wschodzie. Podejmowali je początkowo tzw. anachoreci (gr. anachoretai - ci którzy się oddalili), pustelnicy. Historia przywołuje postać św. Antoniego Pustelnika (ok. 251-356), uważanego za ojca monastycyzmu i św. Pawła z Teb († 347). Gromadzili się przy nich uczniowie, którzy okazjonalnie spotykali się z mistrzem,

Sobór Watykański II, Dekret o przystosowanej odnowie życia zakonnego. Perfectae caritatis, 14 . 
mieszkali zaś w oddzielnych eremach, tworzących z czasem swoiste dialogu osady pustelnicze ${ }^{8}$.

Pararelnie z osadami anachoretów powstawały wspólnoty życia cenobitycznego - wspólnotowego (gr. koinobion - życie we wspólnocie). Za ich twórcę uznaje się św. Pachomiusza (287-346), początkowo pustelnika, który widząc potrzebę wprowadzenia zasad wspólnego przebywania eremitów oraz niejednokrotnie odstraszający surowością sposób ich życia, stworzył zasady zebrane w napisaną w języku koptyjskim i przetłumaczoną na łacinę przez św. Hieronima Regutę zwaną od jej twórcy pachomiańską ${ }^{9}$.

Jednakże największy wpływ na kształt monastycyzmu wschodniego miał św. Bazyli Wielki (ok. 330-379). Po nawróceniu odwiedził on znajdujące się w Górnym Egipcie i Palestynie eremy. Doświadczenie to uczyniło zeń przeciwnika realizowania powołania chrześcijańskiego w samotności. Tłumaczył, że człowiek z natury swej jest bytem społecznym, potrzebuje dla wyrażenia prawdy o sobie drugiego. Odosobnienie nie pozwala także na realizowanie obligatoryjnego w chrześcijaństwie przykazania miłości bliźniego. Dlatego człowiekowi decydującemu się na wyłączną służbę Bogu potrzebni są współbracia, mający te same pragnienia. Bazyli nazywa ich homopsychoi - „ludzie jednomyślni”. Ta jedność miała być odbiciem życia trynitarnego. Jednakże nie była ona osiągalna ludzkimi możliwościami. Mnich miał być tym, który otwierał się na działanie Bożej łaski poprzez szeroko pojętą ascezę. Miała go ona oczyszczać tak, by stawał się on coraz bardziej podobny do swojego Prototypu, którym chciał się stawać i z którym chciał się jednoczyć. Wiodącą rolę odegrać miało w tym Słowo Boga, które powołało człowieka do życia i tylko ono mogło ludzi prawdziwie zjednoczyć pomiędzy sobą. Dla pierwszych uczniów, żyjących w zakładanych przez niego wspólnotach napisał zasady życia monastycznego zwane Regutami Dtu̇̇szymi i Krótszymi ${ }^{10}$.

Od imienia założyciela wschodniego monastycyzmu do dziś, przede wszystkim w katolickich Kościołach Wschodnich wiele wspólnot zakonnych nazywanych jest bazylianami ${ }^{11}$.

8 Por. M. Banaszak, Historia Kościoła katolickiego, t. 1, Warszawa 1989, s. 165.

9 Por. ibidem, s.167.

10 Por.ibidem, s. 170; T. Špidliki.in, Ilmonachesimo secondola tradizione dell'Oriente cristiano, Roma 2007, s. 262; idem, Basilio Magno, [w:] E. Farruggia (red.), Dizionario enciclopedico dell'Oriente Cristiano, Roma 2000, s. 104.

11 Są to Zakon Bazylianów z Grottaferrata, Zakon Bazylianów św. Jozafata, melkicki Zakon Bazylianów Najświętszego Zbawiciela, Zakon Bazylianów św. Jana Chrzciciela często z odpowiednikami żeńskimi. Por. Annuario pontificio per l'anno 1999, Città del Vaticano 2000, s. 1451-1452. 
Poszukując korzeni współczesnego monastycyzmu wschodniego należy wspomnieć o św. Teodorze Studycie (759-826), uważanym za reformatora wschodniego monastycyzmu. Choć potwierdzeniem Teologia dialogu skuteczności tzw. reformy studyckiej był czynnik iście zewnętrzny, w klasztorze Studios za życia Świętego przebywało ok. 300 mnichów. Ogółem klasztory żyjące według reformy Teodora liczyły ponad 1000 zakonników. Świadczyć to może o autentyzmie ich życia, który pociągał wciąż nowych adeptów ${ }^{12}$.

W swojej reformie Teodor Studyta zwrócił uwagę na życie ewangeliczną radą czystości, ubóstwa i posłuszeństwa, na śluby, które nazwał „nowym chrztem”, którego znakiem miał być zakonny habit. Ubóstwo polegać miało nie tylko na wyrzeczeniu się własności prywatnej, ale także, a może przede wszystkim na wolności od rzeczy materialnych, umiarkowaniu i prostocie.

Ślub czystości wyznaczał mnichowi drogę walki duchowej ku zintegrowaniu sfery duchowej ludzkiego życia z materialną. Podkreślał świątynny charakter ciała mnicha i każdego człowieka, z którym się spotyka ostrzegając przez jego profanacją.

Posłuszeństwo zakonne miało być wyrazem „męczeństwa podporządkowania się" własnej wolności zasadom życia wspólnotowego, ustalanych przez przełożonego ${ }^{13}$.

Wprowadzane przez Teodora Studytę zasady życia cenobitycznego, zostały spisane po jego śmierci w Regute - Hypotyposis. Jest ona w monastycyzmie wschodnim o tyle ważna, że przyjęto ją w założonej w X wieku na Górze Athos ławrze, a także w ławrze Pieczerskiej ${ }^{14}$.

Pod koniec XIX wieku, grekokatolicki metropolita lwowski A. Szeptycki, odwołując się do monastycznych zasad św. Teodora Studyty założył istniejący do dziś Zakon Ukraińskich Mnichów Studytów. Od 1920 roku podobną duchowością żyją mniszki studytki ${ }^{15}$.

Inna tradycja monastyczna zachowała się w Kościołach prawosławnych. Męskie i żeńskie klasztory żyją według Reguły św. Bazylego Wielkiego, jednakże mają one autonomię, niezależność od pozostałych, zachowując tzw. Statut Monasterów męskich i żeńskich Świętego Polskiego Autokefalicznego Kościoła Prawostawnego. W innych krajach

12 Por. Benedykt XVI,Św. Teodor Studyta, Audiencja generalna 27 maja 2009 r. http:// www.opoka.org.pl/biblioteka/W/WP/benedykt_xvi/audiencje/ag_27052009.html (dostęp 17 września 2015 r.).

13 Ibidem.

14 Ibidem.

15 Por. W. Osadczy, Studyci, [w:] Encyklopedia Katolicka, t. 18, Lublin 2013, k. 1087. 
istnieją podobne dokumenty, określające zasady życia monastycznego dostosowane do lokalnych potrzeb.

Życie monastyczne w tradycji wschodniej rozpoczyna postuszanije (odpowiednik nowicjatu) po zakończeniu którego dokonywany jest postryg $w$ riasfor. Nie składa się wówczas ślubów, co przynajmniej teoretycznie mówi o możliwości opuszczenia życia monastycznego.

Pierwszym stopniem życia monastycznego, który można przyrównać z junioratem, okresem ślubów czasowych w Kościele łacińskim jest Riasfora. Nazwa pochodzi od długiej, czarnej szaty z szerokimi rękawami, w którą przywdziewany jest tzw. mnich riasoforny. Czas ten, w zależności od rozwoju życia duchowego, kończy się przyjęciem małej schimii, złożeniem dozgonnych ślubów czystości, ubóstwa i posłuszeństwa, a riasfornik staje się mnichem mantijnym i przybiera nowe imię. Warto jest przy tej okazji wspomnieć, że w Kościołach prawosławnych nie istnieje dyspensowanie od matej schimii i związanych z nią ślubów.

Istnieje jeszcze postryg w wielka schimię rozumiany w duchowości Kościoła Wschodniego jako stan bliski życiu anielskiemu. W praktyce osiąga go niewielu. Wielki schimnik poświęca się całkowicie życiu kontemplacyjnemu. Odróżnia go od innych mnichów strój. Nie opuszcza on murów klasztornych, podejmując niemalże nieustanną modlitwę i post jako zadośćuczynienie za grzechy całego świata ${ }^{16}$.

\section{Monastycyzm zachodni}

Naśladowanie Chrystusa poprzez życie ewangelicznymi radami czystości, ubóstwa i posłuszeństwa rozwinęło się także na chrześcijańskim Zachodzie. Bez wątpienia miały na to wpływ tłumaczenia Reguty św. Pachomiusza, których na przełomie IV i V wieku, na język łaciński dokonał św. Hieronim i pism monastycznych św. Bazylego, przełożonych na łacinę w 397 roku przez Rufina z Akwilei. Jeśli dodać do tego powstałe pod koniec IV wieku: Regutę św. Augustyna, Regutę Czterech Ojców (Serapiona, Pafnucego i dwóch Makarych) i Istitutionis św. Jana Kasjana, to nie trudno odtworzyć źródła inspiracji monastycyzmu zachodniego. Ostatecznie niemalże przez sześć wieków tworzono reguły życia monastycznego, którymi do dziś żyją kobiety i mężczyźni ${ }^{17}$.

16 Por. D. Wysocka, O tradycji postrzyżyn na Wschodzie i Zachodzie, „Przegląd Prawosławny" 11(2005), s. 24-26.

17 Por. O. Casel, Wiadomości ogólne, [w:] M. Starowieyski (red.), Zachodnie reguty monastyczne, Tyniec 2013, s. 81. 
Na monastycyzmie zachodnim wsparły się szkoły duchowości chrześcijańskiej, które czerpią z dziedzictwa zakonów, będąc jednakże propozycją nie tylko dla osób konsekrowanych, ale także i świeckich.

Już sama różnorodność reguł życia monastycznego i kręgów kulturowych, z których wywodzą się ich autorzy spowodowała inny niż na Wschodzie „ustrój monastyczny”. Tak zwany I zakon stanowili zebrani wokół mistrza uczniowie, pośród których byli mnisi ze święceniami kapłańskimi i ci, którzy ich nie przyjmowali.

Większością reguł zakonnych, obok mężczyzn pragnęły żyć także kobiety. $\mathrm{Z}$ czasem zaczęły one tworzyć tzw. II zakony. W ten sposób regułą św. Augustyna zaczęły żyć obok augustianów - augustianki; benedyktynów - benedyktynki itp.

W historię monastycyzmu zachodniego wpisane są także tzw. III zakony, do których należą mężczyźni i kobiety, którzy nie rezygnując z powołania właściwego osobom świeckim podejmują życie duchowością zakonodawców. Z tego samego źródła pochodzą także zgromadzenia zakonne i świeckie instytuty życia konsekrowanego prowadzące życie wspólnotowe i żyjące radami ewangelicznymi w świecie.

Kościół Zachodni wprowadził rozróżnienie pomiędzy zakonami kontemplacyjnymi, często zachowującymi tzw. klauzurę papieską i kontemplacyjno-czynnymi, które poświęcają się dziełom apostolskim.

Do osób konsekrowanych do życia ewangelicznymi radami czystości, ubóstwa i posłuszeństwa zaliczane są także dziewice konsekrowane, które

łączą się szczególną więzią z Kościołem lokalnym, któremu służą z poświęceniem, chociaż pozostają w świecie. Żyjąc osobno lub wespół z innymi, są szczególnym eschatologicznym wizerunkiem niebiańskiej Oblubienicy i przyszłego życia, w którym Kościół zazna wreszcie pełni miłości do Chrystusa-Oblubieńca ${ }^{18}$;

pustelnice i pustelnicy, którzy „przez wewnętrzne i zewnętrzne oderwanie od świata świadczą o przemijalności obecnej epoki, a przez post i pokutę ukazują, że nie samym chlebem żyje człowiek, ale słowem Bożym (por. Mt 4, 4)"19; oraz konsekrowane wdowy i wdowcy, którzy „składając wieczysty ślub czystości, przeżywanej jako znak Królestwa Bożego, konsekrują swój stan życia, aby poświęcić się modlitwie i służbie Kościołowi" ${ }^{20}$.

\footnotetext{
18 Jan Paweł II, Vita consecrata, 7.

19 Ibidem.

20 Ibidem.
} 
Warto przy tej okazji wspomnieć także o nowych formach życia kondialogu sekrowanego, wyrosłych z posoborowej odnowy, które niejednokrotnie czerpią z dziedzictwa wczesnego monastycyzmu. Są to tzw. instytuty świeckie i stowarzyszenia życia apostolskiego,

których członkowie pragną przeżywać swoją konsekrację Bogu w świecie poprzez praktykę rad ewangelicznych w kontekście doczesnych struktur, aby w ten sposób być zaczynem mądrości i świadkami łaski w ramach życia kulturalnego, gospodarczego i politycznego. Poprzez syntezę świeckości i konsekracji, która jest ich cechą specyficzną, zamierzają przepajać społeczeństwo nowymi energiami Królestwa Chrystusowego, dążyć do przemiany świata od wewnątrz mocą Błogosławieństw. W ten sposób, choć dzięki swej całkowitej przynależności do Boga są w pełni poświęceni Jego służbie, ich działalność w normalnych warunkach życia w świecie przyczynia się - za sprawą Ducha Świętego - do ożywienia duchem Ewangelii różnych form rzeczywistości świeckich. Dzięki temu Instytuty świeckie zapewniają Kościołowi, każdy zgodnie z własnym charakterem, skuteczną obecność w społeczeństwie ${ }^{21}$.

Kreślenie panoramy monastycyzmu zachodniego i poszukiwanie jej ekumenicznego kontekstu domaga się przyjrzenia rozumieniu życia zakonnego przez XVI-wiecznych reformatorów Kościoła: Marcina Lutra (1483-1546) i Huldrycha Zwinglego (1483-1531), prezbiterów Kościoła rzymskokatolickiego, z których jeden, Luter był także mnichem augustiańskim oraz Jana Kalwina (1509-1554). Byli oni zdecydowanymi przeciwnikami życia zakonnego i autorami wypowiedzi potwierdzających brak ich przekonania do życia w czystości, ubóstwie i posłuszeństwie ${ }^{22}$.

Czym uzasadniają swoje przekonanie? Brakiem ewangelicznych wskazań do takiego sposobu życia. W przekazie reformatorów, składane przez zakonników śluby czystości, ubóstwa i posłuszeństwa są wymysłem ludzkim, absolutnie niechcianym przez samego Boga.

$21 \quad$ Ibidem, 10.

M. Luter, Themata de votis (1521); De votis monasticis iudicium (1521); H. Zwingli, Commentarium de vera et falsa religionis (1525); Aslegung Und Begrundung der Thesen order Artikel (1523); J. Kalwin, De votis, [w:] Institutio religionis Christianae (1559), Libro IV, 13, 1-4. Żadna z tych wypowiedzi nie została przetłumaczona na język polski. Luter poruszał kwestie związane z życiem zakonnym także w innych pismach. Por. Artykuty szmalkaldzkie, Artykut o kolegiach kanoników i klasztorach, III, 1-2; O matżeństwie kapłanów, IX, 1-3; O ślubach mniszych, XIV, 1-3, http://luter2017.pl/wp-content/uploads/pdf/Artyku\%C5\%82y\%20szmalkaldzkie.pdf(dostęp 18 września 2015 r.);Duży Katechizm, Szóste przykazanie, http://luter2017.pl/wp-content/uploads/pdf/DuzyKatechizm. pdf (dostęp 18 września 2015 r.) 
W tzw. Artykułach szmalkaldzkich, w kwestii dotyczącej bezżennej czystości, Luter pisze:

Zakazując małżeństwa duchownych i boski stan kapłański obciążając stałym bezżeństwem, postąpili zdradliwie, bez żadnej uczciwej przyczyny, i w tym dokonali dzieła antychrysta, tyranów i najgorszych niegodziwców, i stworzyli powody do wielu strasznych, wstrętnych, niezliczonych grzechów szpetnych chuci, w których ci dotąd się tarzają. Jak zaś ani my nie mamy, ani oni nie mają mocy, aby z mężczyzny zrobić kobietę lub z kobiety mężczyznę, lub różnicę między płciami zatrzeć, tak i oni nie mają mocy, aby stworzenia Boże rozdzielać, rozłączać i zabraniać, by w małżeństwie uczciwie wspólnie mieszkali i żyli. Dlatego nie chcemy godzić się na haniebne ich bezżeństwo i nie będziemy go także tolerowali, lecz chcemy mieć wolność zawierania małżeństwa, jak je sam Bóg zarządził i ustanowił: Jego dzieła ani nie chcemy zrywać, ani obalać, ani mu przeszkadzać. Paweł bowiem powiada (1 Tm 4, 1-3), że zabranianie małżeństwa jest nauką diabelską ${ }^{23}$.

Wydaje się, że poprzez odniesienie się do teologii św. Pawła - $1 \operatorname{Tm} 4$, 1-3 - praktykę życia w bezżennej czystości, Luter próbuje wyprowadzić za nawias ,zdrowej nauki” i uczynić z niej zaprzeczenie ewangelicznej prawdy. W swoich komentarzach pomija natomiast argument bezżenności Jezusa i tzw. ewangelicznych bezżennych dla sprawy Królestwa Bożego (por. Mt 19,12).

Waldenski teolog Paolo Ricca zwraca także uwagę na inne reformatorskie argumenty przeciwko monastycyzmowi: „stan doskonałości” gwarantowany życiem ewangeliczną radą ubóstwa, czystości i posłuszeństwa nie może dotyczyć wyłącznie osób konsekrowanych, bowiem Ewangelia i jej wskazania są dla wszystkich bez wyjątku ${ }^{24}$.

Reformatorzy kwestionowali także wybór przełożonych na swoistych ojców wspólnot monastycznych. Ricca odnosi się on w tym przypadku do 27 tezy Zwinglego:

Wszyscy chrześcijanie są braćmi Chrystusa i braćmi pomiędzy sobą. Nikogo więc na ziemi nie powinni wyznaczać ojcem. Z tego powodu winne być wykluczone zgromadzenia zakonne, sekty i stowarzyszenia religijne ${ }^{25}$.

Znamienny jest fakt, że efektem działania reformatorów nie była przemiana istniejących klasztorów na odpowiadające duchowi

\footnotetext{
23 M. Luter, Artykuty szmalkaldzkie, Artykuł o kolegiach kanoników i klasztorach, III, 1-2.

24 Por. P. Ricca, Il monachesimo e la reforma protestante, [w:] D. Giordano (red.), Il ruolo del monachesimo nell'ecumenismo, Siena 2002, s. 144. 
Ewangelii, ale ich likwidacja. Taki stan rzeczy dotrwał do XX wieku. dialogu W wyznaniach chrześcijańskich, czerpiących z ducha Reformacji zaczął wówczas tworzyć się ruch, który można nazwać neomonastycyzmem - powrotem do monastycznych, wschodnio- i zachodniochrześcijańskich źródeł i tworzenie wspólnotowego życia radami ewangelicznymi. Zjawisko to można nazwać wypełnieniem swoistej tęsknoty za monastycznym instynktem chrześcijańskim, którego braku nic nie było w stanie wypełnić. W ten sposób powstały męskie i żeńskie instytuty monastyczne, działające w Kościele luterańskim w Niemczech i Skandynawii.

Jedną z takich wspólnot są luterańskie siostry Córki Maryi Ewangelikalnej Drogi Maryi (Daughters of Mary of the Evangelical Way of Mary). Zgromadzenie to zostało założone w Szwecji w połowie XX wieku przez Gunvor Paulinę Norrman, która zapragnęła życia ewangelicznymi radami czystości, ubóstwa i posłuszeństwa. Członkinie założonego przez nią instytutu noszą habity zakonne, zaś część sióstr jednej ze wspólnot (w Vadstenie), odkryła piękno benedyktyńskiej liturgii i podjęła życie Reguta św. Benedykta konwertując się ostatecznie na katolicyzm i włączając nowo powstały klasztor mniszek w Omberg do Kongregacji Benedyktyńskiej ${ }^{26}$.

W XX wieku, na gruncie wspólnot wyrosłych z Reformacji nastąpił także swoisty renesans duchowości franciszkańskiej, którą zaczęli żyć mężczyźni i kobiety w ewangelickim Zakonie św. Franciszka (Evangelische Marienschwestern ${ }^{27}$ i Die Kanaan Franziskusbrüder $\left.{ }^{28}\right)$.

Życie monastyczne w aspekcie tzw. ruchu ekumenicznego zmierzającego do jedności wyznawców Chrystusa towarzyszyło w pierwszej połowie XX wieku Rogerowi Schützowi, który w 1940 roku założył otwartą na wyznawców wszystkich wyznań chrześcijańskich wspólnotę w Taizé. Dał przez to wyraz nie tylko osobistym pragnieniom, ale także możliwości życia monastycznego na gruncie protestantyzmu ${ }^{29}$.

Charakter monastyczny, wsparty o duchowość św. Pachomiusza, św. Bazylego Wielkiego i św. Benedykta z Nursji posiada także założona

26 Por. M. Chamarczuk, Rozwój i działalność żeńskich instytutów życia konsekrowanego $i$ stowarzyszeń życia apostolskiego w Kościele katolickim w Szwecji, „Seminare” 32(2012), s. 139.

27 Luterańskie żeńskie zgromadzenie zakonne, założone w 1947 roku w Darmstadt przez K. Schlink i E. Madaus, liczące obecnie ponad 200 sióstr. Por. http://www. kanaan.org/ (dostęp 18 września 2015 r.)

28 Męska gałąź Marienschwesternschaft. Por. http://www.kanaan.org/de/wir-ueber-uns/die-kanaan-franziskusbrueder/ (dostęp 18 września 2015 r.)

29 Por. L. Schlumberger, Can One Be Protestant and a Monk?, http://www.taize. fr/IMG/pdf/schlumberger_en.pdf (dostęp 18 września 2015 r.) 
w 1965 roku przez Enzo Bianchi ekumeniczna wspólnota z Bose. Jej członkowie, w części protestanci, podejmują życie cenobityczne w czystości, ubóstwie i posłuszeństwie dążąc do ideału pierwszych wspólnot niepodzielonego Kościoła ${ }^{30}$.

Idea życia monastycznego narodziła się w Kościele niepodzielonym. Wyrosła z pragnienia naśladowania Chrystusa i jednoczenia się z Nim poprzez życie w czystości, ubóstwie i posłuszeństwie, którym miały służyć liczne praktyki ascetyczne oraz sposób życia według słów Ora et labora - Módl się i pracuj. Wszystko to sprzyja podstawie jedności, jaką jest wewnętrzne nawrócenie człowieka, bowiem

prawdziwa jedność Kościoła winna być owocem życia duchowego, drogi, która przyjmuje słabość krzyża w którym zwycięża wszechmoc Boga, świętości ukształtowanej na chrześcijańskim obliczu. Nie do przyjęcia jest jedność będąca efektem przymusu, rozumiana jako swoiste bohaterstwo czy też zjednoczenie sił przeciwko komukolwiek, a tym bardziej podyktowana jedynie pragnieniem wzrostu w liczbę czy siłę ${ }^{31}$.

Jeśli jedność Kościoła rozumiana jest jako dzieło, którego dokonać może tylko Bóg to życie monastyczne, poprzez modlitwę do Ojca, przez Chrystusa w Duchu Świętym jest swoistą nieustanną epikleza, wołaniem o Ducha Świętego i Jego jednoczącą moc dla całego Kościoła - mistycznego Ciała Chrystusa, które nie jest podzielone w odróżnieniu od Jego wyznawców.

I wreszcie poprzez

współuczestniczenie w lectio divina w poszukiwaniu prawdy, udział we wspólnej modlitwie, w której Chrystus obiecał nam swoją obecność (por. Mt 18, 20), dialog przyjaźni i miłości, który pozwala odczuć, jak dobrze jest i miło, gdy bracia mieszkają razem (por. Ps 133 [132]), serdeczna gościnność okazywana braciom i siostrom z różnych wyznań chrześcijańskich, wzajemne poznanie i wymiana darów, współpraca $\mathrm{w}$ podejmowanych razem posługach i w świadectwie ${ }^{32}$

dają nadzieję na zjednoczenie się wszystkich wyznawców Chrystusa i pozwalają domniemywać, że przyczyniają się ku temu obecne we wszystkich chrześcijańskich tradycjach formy życia konsekrowanego.

30 Por. http://www.monasterodibose.it/priore/enzo-bianchi (dostęp 18 września 2015 r.)

31 Słowa Metty el Meskina ojca duchownego z klasztoru św. Makarego w Egipcie. Cyt. za E. Bianchi, Il monachesimo Nel movimento ecumenico. Aspetti positivi e negativi, [w:] D. Giordano (red.), Il ruolo del monachesimo, s. 153. 
Teologia dialogu

Słowa kluczowe: monastycyzm, ekumenizm, czystość, ubóstwo, posłuszeństwo, reformacja, Taizé, Bose.

\section{Bibliografia:}

1. Amato A., Il celibato di Gesù, Watykan 2010.

2. Annuario pontificio per l'anno 1999, Città del Vaticano 2000.

3. Banaszak M., Historia Kościoła katolickiego, t. 1, Warszawa 1989.

4. Benedykt XVI, Św. Teodor Studyta, audiencja generalna 27 maja 2009 r. http://www.opoka.org.pl/biblioteka/W/WP/benedykt_xvi/audiencje/ ag_27052009.html (dostęp 17 września 2015 r.).

5. Bianchi E., Il monachesimo Nel movimento ecumenico. Aspetti positivi e negativi, [w:] D. Giordano (red.), Il ruolo del monachesimo nell'ecumenismo, Siena 2002.

6. Brandstaetter R., Czy Jezus z Nazarethu byt cieśla?, [w:] R. Brandstaetter, Jezus z Nazarethu, t. 1-4, Kraków 2013.

7. Casel O., Wiadomości ogólne, [w:] M. Starowieyski (red.), Zachodnie reguty monastyczne, Tyniec 2013.

8. Chamarczuk M., Rozwój i działalność żeńskich instytutów życia konsekrowanego i stowarzyszeń życia apostolskiego w Kościele katolickim w Szwecji, „Seminare” 32(2012), s. 139.

9. Doroszkiewicz W., Dzieje wschodnich Rzymian, Białystok 2012.

10. Jan Kasjan, Rozmów dwadzieścia cztery.

11. Jan Paweł II, Vita consecrata.

12. Kalwin J., De votis, [w:] Institutio religionis Christianae (1559), Libro IV.

13. Luter M., Artykuty szmalkaldzkie, Artykut o kolegiach kanoników $i$ klasztorach.

14. Luter M., De votis monasticis iudicium (1521).

15. Luter M., Themata de votis (1521).

16. Malone E., The Monk and the Martyr, [w:] B. Steidle, Antonius Magnus Eremita, Roma 1956.

17. Osadczy W., Studyci, [w:] Encyklopedia Katolicka, t. 18, Lublin 2013.

18. Popowicz J., Największy spośród niewiast zrodzony, „Przegląd Prawosławny" 9(2006).

19. Ricca P., Il monachesimo e la reforma protestante, [w:] D. Giordano (red.), Il ruolo del monachesimo nell'ecumenismo, Siena 2002.

20. Schlumberger L., Can One Be Protestant and a Monk?, http://www.taize. fr/IMG/pdf/schlumberger_en.pdf.

21. Sobór Watykański II, Dekret o przystosowanej odnowie życia zakonnego. Perfectae caritatis.

22. Špidlik T. i in., Il monachesimo secondo la tradizione dell'Oriente cristiano, Roma 2007.

23. Špidlik T., Basilio Magno, [w:] E. Farruggia (red.), Dizionario enciclopedico dell'Oriente Cristiano, Roma 2000.

24. Wysocka D., O tradycji postrzyżyn na Wschodzie i Zachodzie, „Przegląd Prawosławny" 11(2005).

25. Zwingli H., Aslegung Und Begrundung der Thesen order Artikel (1523)

26. Zwingli H., Commentarium de vera et falsa religionis (1525). 